\title{
Inicjatywy wydawnicze Towarzystwa Nauczycieli Szkół Wyższych na rzecz rozwoju szkoły średniej (wybrane przykłady)
}

\section{Wstęp}

Towarzystwo Nauczycieli Szkół Wyższych (TNSW), które powstało w 1884 r. we Lwowie, cieszy się dużym uznaniem współczesnych badaczy historii oświaty, dziejów bibliotek, książek oraz czasopiśmiennictwa. Jego szeroko zakrojona działalność wydawnicza nadal budzi zainteresowanie, co sprzyja podejmowaniu badań oraz publikowaniu prac na temat edytorskich osiągnięć członków TNSW. Wydawnictwa Towarzystwa Nauczycieli Szkół Wyższych zaliczyć można do źródeł drukowanych, które zajęły czołowe miejsce wśród najbardziej wartościowej spuścizny kulturalnej przełomu XIX i XX stulecia. Są wśród nich prace wybitnych uczonych, głównie narodowości polskiej i niemieckiej, profesorów uniwersyteckich i gimnazjalnych, którzy często byli autorami nowatorskich prac naukowych, a także wzorowych podręczników szkolnych w zakresie nauk ścisłych, polonistyki, filologii klasycznej czy historii. W gronie pedagogicznym gimnazjów galicyjskich znalazła się doborowa kadra nauczycieli, gruntownie wykształconych, którzy równolegle do pracy nauczycielskiej podejmowali własne oryginalne badania naukowe. W znacznym zakresie przyczynili się oni do rozwinięcia badań historycznych, ludoznawczych, etnograficznych, dialektologicznych oraz krajoznawczych ${ }^{1}$. Popularyzowali wiedzę psychologiczną i pedagogiczną wśród dużego grona czytelników.

* Dr, Uniwersytet Jana Kochanowskiego w Kielcach, Wydział Pedagogiczny i Artystyczny, Instytut Edukacji Szkolnej, Zakład Dydaktyki Ogólnej i Wczesnej Edukacji, 25-029 Kielce, ul. Krakowska 11.

1 J. Dybiec, Nauczyciele krakowskich szkół średnich i ich wkład do rozwoju kultury i nauki, [w:] Galicja i jej dziedzictwo. Myśl edukacyjna Galicji 1772-1918, red. C. Majorek, A. Meissner, Rzeszów 1997, t. 8, s. 77-93. 


\section{Działalność wydawnicza TNSW}

Towarzystwo Nauczycieli Szkół Wyższych prowadziło działalność edytorską od pierwszych miesięcy swojego istnienia. Powołano w tym celu odrębną administrację wydawnictwa na czele $z$ administratorem i pięcioosobową komisją administracyjną. Nad pracami wydawniczymi czuwał Wydział Wydawnictw TNSW. Oprócz tego wszystkie serie wydawnicze miały własnych redaktorów odpowiedzialnych za merytoryczny poziom publikowanych prac². W Komisji Wydawniczej pracowali m.in.: Ludwik Finkel, Franciszek Próchnicki, Kazimierz Twardowski, Konstanty Wojciechowski, Emil Petzold, Stanisław Schneider ${ }^{3}$. Za najpilniejszą kwestię uznawano wydawanie podręczników szkolnych dla galicyjskich szkół średnich. Już w 1885 r. na II walnym zgromadzeniu TNSW wysunięto postulat opracowania instrukcji do nauki języka polskiego w szkole średniej oraz wydania słowników i podręczników do nauki języków klasycznych w gimnazjach. W następnym roku propagowano konkurs im. Lindego rozpisany przez Akademię Umiejętności w Krakowie. Przedmiotem konkursu były prace z języka polskiego potrzebne do uzupełnienia Słownika Samuela Bogumiła Lindego ${ }^{4}$.

Działalność wydawniczą TNSW w zakresie czasopiśmiennictwa zainicjowano we Lwowie w 1885 r., rozpoczynając druk i rozprowadzanie miesięcznika pod tytułem „Muzeum”. Nauczyciele szkół średnich, którzy byli członkami Towarzystwa, otrzymywali egzemplarze pisma nieodpłatnie. „Muzeum” stało się najważniejszym organem prasowym Towarzystwa, obejmującym swym zasięgiem Galicję, a w okresie niepodległości cały kraj. Wydawnictwo TNSW rozwijało się dynamicznie, rozważnie zmieniało zasady swojego funkcjonowania, poszerzało ofertę wydawniczą, rozbudowywało sieć dystrybucyjną, aby w okresie Drugiej Rzeczypospolitej po kilku ważnych przekształceniach stać się nowoczesną, dobrze prosperującą spółką. Po 1918 r. uruchomiło kolejne serie periodyków pedagogicznych i opublikowało setki tytułów pozycji książkowych. W latach 1918-1939 na rozwój czasopism pedagogicznych duży wpływ miały zrzeszenia i związki nauczycielskie, które firmowały edycje poszczególnych tytułów, a także nadawały kierunek tematyce publikowanych materiałów. Towarzystwa naukowe i pedagogiczne bardzo dbały o dobór redaktorów oraz dystrybucję własnych wydawnictw. W większości prac wydanych przez TNSW poruszano zagadnienia dydaktyczne, metodyczne, filozoficzne i psychologiczne, prezentowano nowoczesne teorie oraz doświadczenia pedagogiczne. Miało to bardzo duże znaczenie dla uczniów,

2 XXI Sprawozdanie TNSW za czas od 22 maja 1904 do 10 czerwca 1905 r., „Muzeum” 1906, z. 5. Wśród administratorów byli: Karola Rawer, Mariana Janelli, Henryka Kopia. Por.: D. Adamczyk, Polskie społeczne placówki wydawnicze we Lwowie w dobie autonomii galicyjskiej, Kielce 1996, s. $125-143$.

3 [b.a.], ,Muzeum" 1916, nr 10, s. 461.

${ }_{4}^{4}$ Por.: B. Łuczyńska, Koło krakowskie Towarzystwa Nauczycieli Szkół Średnich i Wyższych 1884-1939, Kraków 1991; D. Adamczyk, Polskie społeczne placówki wydawnicze...

${ }^{5}$ W tekście artykułu używać będę oficjalnego skrótu TNSW zamiennie z nazwami: Towarzystwo Nauczycieli Szkół Wyższych i Towarzystwo Nauczycieli Szkół Średnich i Wyższych. 
a także dla nauczycieli, którzy uzupełniali swoją wiedzę i doskonalili umiejętności zawodowe. W roku 1921 na obszarze naszego kraju wychodziło 47 tytułów periodyków pedagogicznych, w 1930 r. 116 tytułów, a w 1938 - 143 tytuły $^{6}$. Na całe dwudziestolecie przypadało ok. 410 tytułów, ale tylko 15 ukazywało się nieprzerwanie, a ok. 60 dłużej niż przez 10 lat. Towarzystwo Nauczycieli Szkół Średnich i Wyższych (TNSW) radziło sobie bardzo dobrze w warunkach konkurencji wydawniczej, edytując 20 tytułów. Od stycznia 1920 r. drugim organem TNSW stał się „Przegląd Pedagogiczny” (1882-1939), do którego dołączono dodatek „Sprawy Towarzystwa”. Jako czasopismo Towarzystwa Nauczycieli Szkół Średnich i Wyższych „Przegląd” ukazywał się w 1921 r. pod redakcją Tomasza Świętochowskiego, w 1922 r. - Lucjana Zarzeckiego, następnie w 1926 r. pod redakcją Henryka Galle, a od 1937 r. - Maksymiliana Tazbira. W latach 1926-1930 „Przegląd Pedagogiczny” połączono ze „Sprawami Towarzystwa” w jeden periodyk. Od 1922 r. w wydawnictwie TNSW Książnica Polska wydawano też kwartalnik naukowy i pedagogiczny zatytułowany „Przegląd Humanistyczny” (1922-1925 Warszawa, 1930-1933 Lwów), którego redakcja mieściła się początkowo w Warszawie, a potem we Lwowie. Był to organ dydaktyczno-sprawozdawczy dla polonistów, historyków, romanistów i germanistów. Kierownictwo redakcji powierzono Wiktorowi Wąsikowi. W „Przeglądzie Humanistycznym” publikowano bibliografię podręczników i pomocy naukowych do przedmiotów humanistycznych nauczanych w szkole średniej (w spisie na rok 1922 znalazło się 161 podręczników). W redakcji pisma pracowali: Stefan Cybulski, Ignacy Halperna, Mikołaj Kłosowski, Lucjusz Komarnicki, Leon Płoszewski). Czwarty z kolei zasługujący na uwagę kwartalnik naukowy i pedagogiczny TNSW to „Przegląd Matematyczno-Fizyczny" pod redakcją Stanisława Straszewicza oraz W. Wojtowicza (1923-1925), który upowszechniał nowe treści z zakresu matematyki oraz fizyki . W 1933 r. Towarzystwo Nauczycieli Szkół Średnich i Wyższych podjęło następną inicjatywę wydawniczą. W Warszawie zaczął ukazywać się kwartalnik TNSW „Kultura i Wychowanie" (1933-1939) pod redakcją Bogdana Suchodolskiego. Był to periodyk prezentujący teoretyczne podstawy pedagogiki kultury, którą uprawiali m.in. Sergiusz Hessen, Bogdan Nawroczyński, Bogdan Suchodolski. Ogółem ukazało się sześć tomów tego czasopisma ${ }^{8}$.

Wprowadzano zmiany w częstotliwości wydawania czasopism. „Muzeum” w bardzo długim okresie swojego ukazywania się (54 lata) było najpierw miesięcznikiem, potem dwumiesięcznikiem, a następnie kwartalnikiem. „Przegląd

${ }^{6}$ J. Jarowiecki, Czasopisma pedagogiczne w Polsce, [w:] Encyklopedia Pedagogiczna, red. W. Pomykało, Warszawa 1993, s. 79.

7 G. Wrona, Lwowskie czasopisma naukowe w latach 1918-1939, [w:] Kraków - Lwów. Książki - czasopisma - biblioteki XIX i XX wieku, red. J. Jarowiecki, WSP w Krakowie, „Prace Monograficzne” 1999, t. IV, nr 258, s. 236-252.

8 I. Wojnar, Z tradycji polskiej pedagogiki kultury, „Kultura i Wychowanie” - kwartalnik 1933-1939, „Przegląd Historyczno-Oświatowy” 1998, nr 3-4, s. 161-167; Ł. Kabzińska, K. Kabziński, Czasopiśmiennictwo pedagogiczne okresu II Rzeczypospolitej jako źródło refleksji teoretycznej w zakresie dydaktyki, [w:] Czasopiśmiennictwo okresu drugiej Rzeczypospolitej jako źródło do historii edukacji, red. I. Michalska, G. Michalski, Łódź 2010, s. 215-227. 
Pedagogiczny" po licznych zmianach sprowadzono do roli dwutygodnika informacyjnego, redagowanego przez Maksymiliana Tazbira.

Od roku 1923 w wydawnictwie Książnica Polska TNSW nakładem własnym ukazywało się pismo dla młodzieży „Iskry”, jako dwutygodnik, pod redakcją Władysława Kopczewskiego, z corocznym dodatkiem „Kalendarz Iskier”. „Iskry” dążyły do nawiązania dobrych kontaktów z młodymi czytelnikami, służyły pomocą w sprawach szkolnych, popularyzowały różne dyscypliny sportowe, oferowały rozrywki umysłowe, zagadki, rebusy, anegdoty. Jako organy sekcji Towarzystwa Nauczycieli Szkół Średnich i Wyższych przez pewien okres ukazywały się także inne periodyki, np. „Szkolnictwo Zawodowe” (1927-1932), organ Zarządu Głównego Sekcji Nauczycieli Szkół Zawodowych, oraz miesięcznik „Pedagogium” (1925-1932), organ Zarządu Głównego Sekcji Seminariów Nauczycielskich. Wydawano też serie książek dla młodzieży, w dużych nakładach nowe podręczniki szkolne lub ich kolejne wznowienia oraz dzieła pomocnicze dla nauczycieli9.

Wobec ogromnego rozkwitu akcji wydawniczej już w 1916 r. powołano Towarzystwo „Książnica Polska TNSW”, które w 1924 r. przekształcono w prężnie rozwijającą się spółkę akcyjną „Książnica Atlas TNSW”. Spółka powstała w wyniku połączenia „Książnicy Polskiej” Spółki Akcyjnej Kartograficznej i Wydawniczej TNSW we Lwowie z „Atlasem” Spółką Akcyjną, Kartograficzną i Wydawniczą we Lwowie ${ }^{10}$. Prezesem Rady Nadzorczej został znakomity geograf Eugeniusz Romer. Na rezultaty nie trzeba było długo czekać. W nowej spółce wydawniczej dla młodzieży szkolnej zakwalifikowano do druku ponad 600 książek. „Książnica” opublikowała wkrótce Katalog książek dla bibliotek szkolnych, czyli spis książek beletrystycznych zakwalifikowanych przez MWRiOP, obejmujący wydawnictwa własne. Siedzibą nowego wydawnictwa były miasta Lwów oraz Warszawa. Katalog przygotowano z myślą o nauczycielach, dyrektorach szkół oraz rodzicach. W księgarniach „Książnicy Atlas” spółki Zjednoczonych Zakładów Kartograficznych Towarzystwa Nauczycieli Szkół Średnich i Wyższych oferowano wszystkie wydawnictwa polskie (naukowe, pedagogiczne, dydaktyczne, podręczniki szkolne, mapy, atlasy, globusy, przewodniki turystyczne, a także prenumeratę pism krajowych i zagranicznych $)^{11}$. „Książnica” w latach międzywojennych publikowała też miesięcznik poświęcony krytyce i bibliografii wydawnictw własnych, czyli „Przegląd Wydawnictw” pod red. Jana Piątka i Emila Żychiewicza, a także w formacie kieszonkowym pisemko „Wici” ${ }^{12}$. W okresie 20-lecia wydawano też pisma „Rocznik Pedagogiczny” (1923-1930, red. Helena Radlińska) oraz „Przyroda i Technika" (od 1922 r., red. Benedykt Fuliński). Największym uznaniem wśród czytelników cieszyły się wydawnictwa kartograficzne oraz podręczniki szkolne.

${ }^{9}$ S. Możdżeń, J. Musiał, Bibliografia polskich czasopism pedagogicznych (do 1979 r.), Kielce 1981.

${ }^{10}$ Na mocy postanowienia Ministerstwa Przemysłu i Handlu oraz Skarbu z dnia 26 kwietnia $1924 \mathrm{r}$.

11 W księgarniach można było zamówić cały zestaw książek do biblioteki szkolnej. Por.: Katalog książek dla bibliotek szkolnych, Lwów, Warszawa 1928.

12 „Przegląd Wydawnictw Książnicy Atlas” ukazywał się jako miesięcznik, a od 1929 r. jako kwartalnik. W tym samym roku uruchomiono osobne pisemko bibliograficzne "Wici". 
Lista autorów podręczników tylko z okresu międzywojennego obejmuje ponad sto nazwisk, a tytułów opublikowanych książek ponad tysiąc ${ }^{13}$. Należy podkreślić, że do periodyków cieszących się autorytetem zarówno ogólnokrajowym, jak i międzynarodowym, odgrywających dużą rolę w upowszechnianiu dorobku tak polskiej, jak i światowej pedagogiki, inicjujących szereg działań na rzecz rozwoju szkoły średniej, należało w pierwszej kolejności czasopismo „Muzeum”14.

„Muzeum” można zaliczyć do pism niezwykle bogatych w materiały źródłowe m.in. z dziedziny polityki oświatowej, problematyki kształcenia nauczycieli, reformy ustroju szkół średnich, modernizacji procesu dydaktyczno-wychowawczego w gimnazjach. Do dziś pozostaje niewykorzystanym w pełni źródłem do badań bibliograficznych oraz biograficznych, a zamieszczane na jego łamach publikacje znakomitych autorów mogą nadal służyć budowaniu „historii czyjegoś życia”15. Wiedza o działalności Towarzystwa Nauczycieli Szkół Wyższych, a w pewnym stopniu również innych towarzystw oświatowych (na przykład Towarzystwa Pedagogicznego) może być rekonstruowana na podstawie analizy zawartości „Muzeum”, gdyż pismo powołano dla realizacji założeń programowych Towarzystwa. Pierwszy numer miesięcznika „Muzeum” ukazał się 15 stycznia 1885 r. we Lwowie pod redakcją Romana Palmsteina. Przez następne cztery lata redaktorem naczelnym był Maurycy Maciszewski, a po nim aż przez dwadzieścia pięć lat Bolesław Mańkowski. Redakcja skupiła wokół siebie grono stałych współpracowników, byli wśród nich: Franciszek Majchrowicz, Roman Zawiliński, Aleksander Radecki, Józef Czernecki, Maurycy Maciszewski, Zygmunt Samolewicz, Tomasz Sołtysik. Jako organ prasowy TNSW „Muzeum” wiele miejsca na swoich łamach przeznaczało na „Sprawy Towarzystwa” oraz „Sprawozdania z Walnych Zgromadzeń” (od 1893 r. drukowano je z osobną paginacją). W dziale „Rozprawy Naukowe" zamieszczano początkowo prace filologiczne i historyczne oraz dotyczące zagadnień nauczania w języku ojczystym i języka polskiego jako przedmiotu. Wydawcami pierwszych szkolnych wypisów z literatury byli współpracownicy redakcji „Muzeum”, m.in.: Wiktor Hahn, Tadeusz Pini, Konstanty Wojciechowski. Brali oni udział w opracowaniu objaśnień oraz wstępów literacko-historycznych serii „Arcydzieła Polskich i Obcych Pisarzy”16. Naczelny redaktor Bolesław Mańkowski, który kierował redakcją od 1 stycznia1890 r., doprowadził czasopismo „Muzeum” do rozkwitu17. Początkowo jeden zeszyt pisma obejmował 4 arkusze

13 Wychowanie i nauczanie. Przewodnik do wydawnictw pedagogicznych $i$ dydaktycznych S.A. Książnica Atlas TNSW, oprac. J. Piątek, K. Sośnicki, Lwów-Warszawa 1932.

14 A. Molak, Z dziejów polskiej prasy pedagogicznej, „Nowa Szkoła”1961, nr 10; W. Czerniszewski, Czasopisma pedagogiczne w Polsce okresu międzywojennego, „Nowa Szkoła” 1968, nr I0/11; S. Możdżeń, J. Musiał, Bibliografia polskich czasopism pedagogicznych...

15 G. Michalski, Źródła do badań biograficznych w historii wychowania, [w:] Konteksty i metody w badaniach historyczno-pedagogicznych, red. T. Jałmużna, I. Michalska, G. Michalski, Kraków 2004, s. 180.

16 Szerzej na ten temat: J. Błażejewska, Dyskusja wokół funkcji i zadań bibliotek szkolnych na łamach galicyjskiego „Muzeum” (1885-1918), [w:] Kraków-Lwów. Książki - czasopisma - biblioteki, red. H. Kosętka, „Prace Monograficzne Akademii Pedagogicznej w Krakowie” 2005, t. VII, nr 409, s. $218-230$.

17 Bolesław Ferdynand Mańkowski (1852-1921), profesor pedagogiki Uniwersytetu Lwowskiego, dyrektor Biblioteki Uniwersyteckiej, Polski Słownik Biograficzny, t. XIX, Wrocław 1974, s. 515-516. 
druku, ale już od 1906 r. liczył 20 arkuszy zebranych w dwóch obszernych tomach rocznie. Dzięki subwencjom Sejmu Krajowego oraz Ministerstwa Wyznań i Oświaty można było zwiększyć również honoraria autorskie. Wiele inicjatyw wydawniczych świadczyło o trosce o wychowanie młodzieży oraz staranne jej wykształcenie. Wydawana przez TNSW „Biblioteka dla Młodzieży” była prowadzona przez J. Skupniewicza, a potem przez K. Rawera. Celem tego przedsięwzięcia wydawniczego było „... dać młodzieży do ręki książki pięknie wydane a tańsze jak prywatni wydawcy, po wtóre zaś ochronić nauczycieli-autorów od wyzyskiwania nakładców..."18. W pierwszym dziesięcioleciu działalności wydawnictwa TNSW opublikowano 85 tytułów książek, łącznie z dziesięcioma tomami roczników „Muzeum". Szczególną rolę w dziedzinie podnoszenia poziomu pracy szkoły średniej przypisywano właśnie bibliotekom szkolnym, a co się z tym wiąże doborowi lektur, formom pracy z młodzieżą, a nawet kontroli lektur domowych, czyli tego, co czytywali uczniowie w czasie wolnym. Pierwszy spis książek dla młodzieży zamieszczono w „Muzeum” w 1892 r., a był on efektem pracy nauczycieli szkół Iwowskich. Oprócz treści książek dla młodzieży ocenie poddawano też poprawność pisowni zalecanych wydawnictw. Towarzystwo Nauczycieli Szkół Wyższych rozpoczęło w 1901 r. przegląd zasobów bibliotek szkolnych. Niestety, biblioteki były na ogół źle zaopatrzone, a system wypożyczania (bibliotekarzem był przeważnie jeden spośród nauczycieli, w niektórych szkołach zakazywano wypożyczania książek uczniom młodszych klas gimnazjów) pozostawiał sporo do życzenia ${ }^{19}$. Postulowano, by przy TNSW powołać Komisję Kwalifikującą Książki do Bibliotek Szkół Średnich, której zadaniem miało być ocenianie książek oraz zamieszczanie obszernych recenzji na łamach „Muzeum” w rubryce „Książki dla młodzieży”. W każdym numerze pisma starano się też zamieszczać opinie o pismach młodzieżowych, a nawet postulowano, by przygotować broszurę o wydawnictwach dla uczniów, co mogłoby być drukowaną formą stałego "sądu konkursowego" opiniującego przygotowywane do druku „książeczki dla młodzieży”20. Reklamowano także inne periodyki, zachęcając do ich prenumeraty i wykorzystania w pracy z uczniami. Polecano „Przewodnik Bibliograficzny” pod redakcją W. Wisłockiego, czasopismo „Kosmos” redagowane przez Bronisława Radziszewskiego, dwutygodnik dla młodzieży „Przyrodnik” pod redakcją Z. Morawskiego i wiele innych. Zachęcano do kupowania książek wydawanych przez wydawnictwo Kasy im. Mianowskiego w Warszawie. Rozwój rynku wydawniczego wpływał na poziom edytorski kolejnych książek drukowanych przez Towarzystwo i wydawanych jego nakładem. Przykładowo Botanika szkolna Józefa Rostafińskiego była ozdobiona 554 figurami w drzeworytach, podwójną barwną tablicą oraz kartą roślin. 1894.

18 M. Warmski, Towarzystwo Nauczycieli Szkół Wyższych 1884-1894. Rys historyczny, Lwów

19 Szerzej na ten temat: K. Wojciechowski, W sprawie bibliotek i czytelni dla młodzieży w szkołach średnich, „Muzeum” 1902, s. 39; J. Kubliński, Jak należy zorganizować lekturę prywatną, aby przyczyniła się do pogłębienia wiedzy bez przeciążania uczniów?, „Muzeum” 1903, s. 190.

20 [b.a.], Książki do biblioteki uczniów, „Muzeum” 1892, s. 427; S. Leonhard, Komisja kwalifikująca książki do bibliotek uczniów, „Muzeum” 1907, t. II, s. 22. 
U schyłku XIX wieku pojawił się w wydawnictwie Towarzystwa miesięcznik „Przyjaciel Młodzieży”, który poczynając od 1 stycznia 1899 r. redagował Henryk Kopia we współpracy z Franciszkiem Krcekiem, Kornelem Fischerem, Józefem Szafranem i Mieczysławem Warmskim. W każdym zeszycie „Muzeum” ogłaszano „Wiadomości Bibliograficzne”. W 1887 r., z inicjatywy koła przemyskiego TNSW, uchwalono wydanie kalendarza dla uczniów, który miał zawierać kalendarz astronomiczny, kalendarz kościelny oraz informator na nowy rok szkolny. Od 1909 r. w osobnych dodatkach do „Muzeum” i z osobną numeracją stron ukazywały się prace z zakresu dydaktyki i historii oświaty w Polsce. Były wśród nich rozprawy debiutujących na łamach pisma wybitnych polskich uczonych, m.in. Stanisława Kota i Antoniego Karbowiaka ${ }^{21}$. Pierwszy dodatek miał charakter jubileuszowy, poświęcony na omówienie działalności TNSW, inne posiadały walory naukowo-dydaktyczne i były prezentacją badań profesorów szkół galicyjskich na temat Juliusza Słowackiego, bibliografii druków odnoszących się do Komisji Edukacji Narodowej, ruchu pedagogicznego w Królestwie Polskim w dobie bojkotu szkolnego, szkolnictwa parafialnego w Małopolsce w XVI-XVIII wieku, pierwszego polskiego czasopisma pedagogicznego. W 1923 roku z okazji 150. rocznicy KEN w hołdzie komisji i Stanisławowi Konarskiemu wydano interesującą pracę zbiorową pt. Epoka Wielkiej Reformy pod red. S. Łempickiego.

Okresy stagnacji w działalności TNSW wpływały na spadek popularności czasopisma, spowodowały też, że poziom zamieszczanych w nim artykułów był nieco słabszy. Towarzystwo w trosce o swoją przyszłość, a także pomyślny rozwój wydawnictwa, 12 czerwca 1905 r. wybrało na nowego prezesa Kazimierza Twardowskiego, 39-letniego wówczas profesora Uniwersytetu Lwowskiego, człowieka żelaznej energii, a także wielkiej pracowitości. Profesor K. Twardowski był prezesem TNSW do 5 czerwca $1911 r^{22}$ Za sprawą jego inicjatywy i dzięki dużemu nakładowi pracy odnotowano w czasopiśmie „Muzeum”, jak i w działalności Towarzystwa szereg korzystnych zmian, m.in. wzrósł nakład „Muzeum”: w 1905 r. opublikowano 1100 egzemplarzy (1316 stron), a w 1911 r. 2150 egzemplarzy (2162 strony), poszerzyło się grono współpracowników, podniosła się jakość publikowanych materiałów ${ }^{23}$. Swoista walka o „rewizję” bibliotek szkolnych przynosiła stopniową poprawę wyposażenia bibliotek, wzrost zainteresowania czytelnictwem, rozwój badań, wzrost liczby prac naukowych. Łamy "Muzeum” udostępniano w pierwszej kolejności pedagogom, którzy walczyli o polską szkołę, o reformy szkół średnich, a także o poprawę pozycji zawodowej nauczycieli gimnazjalnych ${ }^{24}$. Nauczyciele gimnazjów galicyjskich nie tylko ustawicznie się

${ }^{21}$ Antoni Karbowiak opublikował na łamach „Muzeum” 28 artykułów z dziedziny historii wychowania.

22 K. Zagajewski, Profesor Kazimierz Twardowski jako prezes TNSW, „Muzeum”1936, R. 51, z. 2. Był to specjalny zeszyt w 70. rocznicę urodzin profesora, honorowego członka TNSW, wydany w uznaniu jego zasług.

${ }^{23}$ Nadal toczy się dyskusja na temat objętości czasopism oraz ich nakładów. Por.: J. Jarowiecki, Typologia i statystyka prasy Iwowskiej w latach 1864-1939, [w:] Kraków - Lwów. Książki - czasopisma - biblioteki XIX i XX wieku, „Prace Monograficzne WSP im. KEN w Krakowie” 1999, t. IV.

24 Por. I. Moszczeńska, Strajk szkolny w Królestwie z punktu widzenia wychowawczego, „Muzeum” 1905, s. 537; H. Orsza, Z pamiętnych dni oraz W sprawie polskiego dorobku wychowawczego, 
dokształcali, składali egzaminy kwalifikacyjne, uprawiali własną twórczość naukową, niekiedy pracując bezpłatnie na uniwersytetach, a na państwowych posadach - w gimnazjach. Niezbędną pomoc stanowiły dla nich zasoby bibliotek naukowych, a także biblioteki nauczycielskie w szkołach ${ }^{25}$. Kwestia bibliotek szkolnych była na przełomie XIX i XX stulecia „sprawą palącą”.

Profesorowie gimnazjalni rezultaty swych badań publikowali najczęściej w Wydawnictwie TNSW. „Muzeum” zamieszczało również liczne noty bibliograficzne prac ogłaszanych przez nauczycieli w innych periodykach oraz w sprawozdaniach gimnazjów. Sprawozdania profesorów szkół średnich często ukazywały się także jako broszury samoistne, a w „Muzeum” notowano skrupulatnie ich wydanie. Spisy rozpraw zamieszczanych w sprawozdaniach szkół średnich galicyjskich, polskich i ruskich, a także Śląska Cieszyńskiego, opublikowanych w latach 1894-1914, obejmują dziesiątki pozycji i stronic w każdym roczniku czasopisma ${ }^{26}$. W „Wiadomościach Bibliograficznych” zamieszczano omówienia książek dla młodzieży oraz recenzje czasopism polskich i zagranicznych, takich jak „Educational Review” czy „School and Home Education”. W 1901 r. pojawił się dział „Literatura pedagogii i psychologii wychowania”, który dotyczył prac opublikowanych w języku niemieckim, zamieszczanych głównie w czasopiśmie „Die Kinderfehler. Zeitschr. F. Pädagogische Pathologie und Therapie in Haus, Schule und Socialen Leben". Prace w języku francuskim omawiano za „Lannee psychologique”. W „Muzeum”, dzięki przychylności TNSW, na stałe zagościły też artykuły, sprawozdania, relacje ze szkół nurtu nowego wychowania oraz systemów szkolnych wielu krajów. Były to początki badań porównawczych oraz nowatorstwa pedagogicznego.

W latach poprzedzających wybuch I wojny światowej nastąpiło zmniejszenie objętości czasopisma i obniżenie budżetu wydawnictwa z powodu oszczędności wprowadzonych przez TNSW. W 1914 r. ukazał się tom I (zeszyty 1-5) oraz zeszyt 1 tomu II; w 1916 r. ograniczono objętość pisma do 464 stron w całym roczniku, wprowadzono cienki papier i mniejszy druk. Częste zmiany na stanowisku redaktora nie sprzyjały dobremu poziomowi artykułów i recenzji, ale mimo to w latach 1916-1919 czasopismo starało się być łącznikiem między nauczycielami trzech zaborów, reagowało na aktualne wydarzenia polityczne i wojenne. Po odzyskaniu niepodległości wiele wydawnictw (w tym czasopisma pedagogiczne) przeżywało kłopoty finansowe, a pisma o radykalnym charakterze napotykały problemy ze strony władzy oraz cenzury. To sprawiło, że tylko 60 tytułów ukazywało się dłużej niż przez 10 lat, a 15 wychodziło przez cały okres międzywojenny. Wśród tych ostatnich znalazło się „Muzeum”27.

\footnotetext{
„Muzeum” 1909, t. I, s. 29 i t. II, s. 32; A. Karbowiak, Rusyfikacja i bojkot szkół w Królestwie Polskim, „Muzeum” 1908, t. II, s. 99.

25 J. Dybiec, Rola Biblioteki Jagiellońskiej w rozwoju nauczycielskiego ruchu naukowego w Galicji w latach 1867-1914, [w:] Kultura książki w Krakowie doby autonomii galicyjskiej, red. M. Kocójowa, Wrocław 1991; M. Stinia, Szkolne biblioteki nauczycielskie gimnazjów krakowskich w okresie autonomii 1867-1918, [w:] Kraków - Lwów. Książki - czasopisma - biblioteki, red. H. Kosętka, „Prace Monograficzne AP w Krakowie" 2005, t. VII, nr 409, s. 210-217.

26 Bibliografia dziejów oświaty i wychowania w Galicji 1772-1918, red. A. Meissner, S. Możdżeń, Rzeszów 1992.

27 S. Możdżeń, J. Musiał, Bibliografia polskich czasopism pedagogicznych..., s. 22-23.
} 
Od 1920 r. „Muzeum” wydawane było przez Okręg Lwowski Towarzystwa Nauczycieli Szkół Średnich i Wyższych. W pierwszym półroczu 1920 r. redagowali pismo Ludwik Jaxa-Bykowski i Marian Janelli, a dalej redakcję prowadził tylko L. Jaxa-Bykowski. „Muzeum” wydawano przez następnych dziesięć lat jako kwartalnik poświęcony dydaktyce i metodyce nauczania w szkole średniej. Od 1921 r. wprowadzono zasadę poświęcania całego zeszytu jednemu zagadnieniu (np. filozofii, pedagogice, filozofii klasycznej, polonistyce, naukom matematyczno-przyrodniczym). Rok 1931 przyniósł zmianę częstotliwości ukazywania się czasopisma - wychodziło co 2 miesiące ${ }^{28}$. Do 1936 r. redaktorem naczelnym był Kazimierz Brończyk, a od połowy 1936 r. do 1939 r. - Władysław Olszewski.

Czasopismo „Muzeum” stanowi bardzo bogate źródło faktograficzne do dziejów oświaty polskiej, zarówno okresu galicyjskiego, jak i Polski Odrodzonej. Jest niezastąpionym zbiorem informacji o działalności wydawniczej Towarzystwa Nauczycieli Szkół Wyższych za lata 1884-1939. W okresie galicyjskim użytkowano w szkołach 47 podręczników wydanych nakładem TNSW oraz liczne lektury z zakresu literatury polskiej i obcej wydawane w seriach „Biblioteka dla Młodzieży”, „Biblioteka Klasyków Greckich i Łacińskich”, „Biblioteka Dzieł Literatury Niemieckiej”. Serię prac „Nauka i Sztuka” wydanych przez TNSW, która obejmowała 13 monografii, redagował Tadeusz Pini (do 1912 r.), a następnie Mieczysław Treter. Wymienione serie wydawnicze przeznaczone były do użytku nauczycieli i uczniów gimnazjów, ale krąg odbiorców był znacznie szerszy.

W przededniu odzyskania niepodległości w kilku rocznikach „Muzeum” oraz w sprawozdaniach z walnych zgromadzeń odnotowano z satysfakcją utworzenie nowego wydawnictwa Towarzystwa Nauczycieli Szkól Wyższych pod nazwą „Książnica Polska”. W latach międzywojennych w „Sprawach Towarzystwa” wielokrotnie informowano czytelników o publikacjach ukazujących się w tym wydawnictwie. „Książnicę Polską” na mocy decyzji Zarządu Głównego TNSW wyodrębniono z dotychczasowych wydawnictw Towarzystwa Nauczycieli Szkół Wyższych. Poczynając od 1916 r. „Książnica” działała jako samodzielna placówka nakładowa (na zasadzie spółki z ograniczoną odpowiedzialnością), której udziałowcami byli profesorowie szkół średnich i wyższych - członkowie TNSW oraz samo Towarzystwo. Zebranie założycielskie odbyło się 13 kwietnia 1916 r. ${ }^{29}$ Od tamtej pory każdy zeszyt czasopisma zawierał informacje o nowościach wydawniczych wspomnianej spółki.

Na łamach czasopisma „Muzeum” obserwujemy rozwój szeregu cennych inicjatyw badawczych oraz początki polskiej historiografii oświatowej ${ }^{30}$. Przykładowo

${ }^{28}$ W latach 1926-1929 „Muzeum” ukazywało się jako periodyk ogólnopolski. Wykaz redaktorów oraz współpracowników pisma można znaleźć m.in. w pracy B. Łuczyńskiej, Koło Krakowskie TNSW na tle prac...

${ }_{29}$ [b.a.], „Muzeum” 1916, nr 10, s. 461; „Muzeum” 1918, nr 6, s. 368; G. Wrona, Działalność wydawnicza Towarzystwa Nauczycieli Szkół Wyższych w latach 1885-1914, [w:] Życie społeczno-kulturalne ośrodków lokalnych ziem polskich w dobie popowstaniowej (1864-1914), red. M. Adamczyk, A. Notkowski, Kielce-Warszawa 1993, s. 330-341.

30 Por.: W. Szulakiewicz, Historia oświaty $i$ wychowania w Polsce 1918-1939. Studium historiograficzne, Toruń 2000, s. 84. 
Antoni Karbowiak opublikował odezwę Komisji do Badań Dziejów Literatury i Oświaty w Polsce AU w Krakowie zatytułowaną $W$ sprawie badań dziejów wychowania i szkół w Polsce, zapoczątkowując rozwój historiografii pedagogicznej31. Liczne prace autorstwa nauczycieli gimnazjów (m.in. Mieczysława Baranowskiego, Jana Leńka, Franciszka Majchrowicza, Franciszka Bizonia, Antoniego Danysza, Jana Buzka) rozpoczynają bogaty i zróżnicowany nurt badawczy historiografii oświatowej, który zaowocował szeregiem interesujących publikacji. W okresie międzywojennym łamy czasopisma "Muzeum" na równi z czasopismem „Kultura i Wychowanie” były najczęściej wybierane do publikacji rozpraw naukowych historyków wychowania ${ }^{32}$. Wspomniany wcześniej A. Karbowiak zamieścił w „Muzeum” scenariusz ekspozycji osiągnięć szkoły polskiej za lata 1740-1894, a dalszym ciągiem tej inicjatywy było przekształcenie wystawy w stałe muzeum szkolne, istniejące we Lwowie od 1907 r. dzięki usilnym staraniom Ludomiła Germana, wizytatora szkół i prezydenta parlamentu wiedeńskiego ${ }^{33}$.

Wiedzę o różnych obszarach działalności Towarzystwa Nauczycieli Szkół Wyższych przyniosły prace współczesnych historyków oświaty, m.in. Janiny Chodakowskiej, Barbary Łuczyńskiej, Grzegorza Michalskiego ${ }^{34}$.

Niektóre z koncepcji wychowawczych oraz rozwiązań dydaktycznych przetrwały do dnia dzisiejszego. Jako przykład może posłużyć inicjatywa wspierania rozwoju wychowania fizycznego oraz ruchu higienistów i lekarzy szkolnych. Powszechne narzekania na przepełnienie szkół gimnazjalnych oraz złe warunki pracy nauczycieli i uczniów równoważono informacjami o wartościowych metodach i formach pracy w szkołach średnich ${ }^{35}$. Doceniając zagadnienia wychowania fizycznego, a w pierwszej kolejności zdrowia i higieny młodzieży szkolnej, na łamach czasopism wiele uwagi poświęcono kulturze fizycznej, prezentując działalność Henryka Jordana, jego parku oraz „studenckich” warsztatów pracy ręcznej. Wprowadzono je do szkół w 16 miastach Galicji, szeroko propagując ich wartości na łamach „Muzeum”(przykładowo w 1907, 1910 i w 1911 roku). Park jordanowski był pomysłem fenomenalnym, niespotykanym w skali europejskiej, jeśli chodzi o rozmiar oraz jakość przedsięwzięcia. W 1889 roku otwarto w okolicy Błoń nad Rudawą wielki park sportowy dla dzieci i młodzieży miasta Krakowa. Park zajął obszar 19 hektarów, na których po splantowaniu i zazielenieniu (posadzono ponad sto tysięcy drzew i krzewów) urządzono dwanaście boisk sportowych,

31 Tamże, s. 19; „Muzeum” 1901, s. 309-316.

32 Jak ustaliła W. Szulakiewicz, w obu czasopismach zamieściło swoje prace po ośmiu autorów, co stanowiło $12,31 \%$ publikujących. Wyprzedzała te periodyki w niewielkim stopniu „Nauka Polska” z 9 autorami, czyli 13,85\% publikujących.

33 „Muzeum” 1893, s. 710-721; „Muzeum” 1894, s. 924-934.

34 J. Chodakowska, Udział TNSW w walce o polską szkołę średnią w Galicji, „Rozprawy z Dziejów Oświaty" 1984, t. XXVI, Wrocław; B. Łuczyńska, TNSW wobec problemów nauczycieli szkół średnich (1884-1918), Kraków 1984; G. Michalski, Towarzystwo Nauczycieli Szkół Średnich i Wyższych w Łodzi w okresie międzywojennym, [w:] Tradycje i współczesność łódzkich szkół średnich, red. T. Jałmużna, Łódź [b.r.w.].

${ }^{35} \mathrm{~Np}$. A. Haratyk, Kolonie wakacyjne dla uczniów galicyjskich szkół średnich w świetle sprawozdań zamieszczonych w czasopiśmie „Muzeum”, „Acta Universitatis Wratislaviensis” 1996, Prace Pedagogiczne 113, Wrocław. 
strzelnicę, kort tenisowy, budynek z natryskami, szatnie dla chłopców i dziewcząt, magazyny z przyborami i przyrządami gimnastycznymi, pijalnię mleka. Na terenie parku ustawiono przyrządy do ćwiczeń: pomosty, drabinki, równoważnie itp., a na starannie pielęgnowanych trawnikach 44 popiersia sławnych Polaków. Młodzież korzystała z parku w sposób zorganizowany, pod opieką instruktorów. Warsztaty pracy ręcznej, tzw. „studenckie”, które otwarto na terenie parku w 1906 r., wyposażono w 21 strugnic, 4 tokarki, stół do prac ślusarskich, introligatorskich. $\mathrm{Na}$ działkach kwiatowych i warzywnych pracowało ponad tysiąc dziewcząt i chłopców. Henryk Jordan troszczył się o wychowanie fizyczne młodzieży, ale także o jej wychowanie estetyczne, techniczne, moralne i patriotyczne ${ }^{36}$. Jego inicjatywy w zakresie wychowania pozaszkolnego spotykały się z uznaniem na terenie całego kraju i poza jego granicami, tworzyły oryginalny system wychowania i rekreacji młodzieży szkolnej. Uruchomiły aktywność społeczną w dziedzinie wychowania fizycznego oraz zainteresowanie pracą ręczną jako środkiem wychowawczym ${ }^{37}$.

$\mathrm{Na} ł a m a c h$ czasopism zamieszczano też wiele artykułów na temat higieny szkolnej i konieczności zatrudniania w szkołach lekarzy higienistów. Publikowano petycje i memoriały TNSW do dyrektorów szkół średnich oraz rozporządzenia władz szkolnych w sprawach zdrowotnych i higienicznych. Na zjazdach i walnych zgromadzeniach uchwalano rezolucje w sprawie reformy wychowania fizycznego. Propagowano inne czasopisma wydawane przez stowarzyszenia nauczycielskie, np. „Przewodnik Gimnastyczny”, „Sokół”. Opublikowano szereg artykułów popularyzatorskich zarówno w zakresie dorobku myśli pedagogicznej, jak i praktycznych rozwiązań w dziedzinie wychowania fizycznego stosowanych w krajach europejskich. Relacjonowano przebieg zjazdów międzynarodowych kongresów wychowania fizycznego, poczynając od I Kongresu, który odbył się w 1900 r. w Paryżu, następnie Kongresów w 1905 r. w Leodyum, w 1910 r. w Brukseli, w 1911 r. w Rzymie i ponownie w 1911 r. w Odense (Dania). Zjazdy krajowe lekarzy i przyrodników zwoływano w Krakowie, we Lwowie, a także w Warszawie i Lublinie. Nie pomijano również innych dziedzin wychowania, np. estetycznego i muzycznego, pisząc m.in. o muzyce w gimnazjach i szkołach realnych oraz doniosłości nauki rysunków ${ }^{38}$. Po 1905 r. redaktorzy „Muzeum” opublikowali kilkanaście dodatków do czasopisma jako samoistne broszury, wśród których znalazły się prace dotyczące projektów i planów 8-klasowej szkoły realnej, gminy szkolnej im. Jędrzeja Śniadeckiego w gimnazjum we Lwowie, materiały do nauki języka polskiego oraz działalności warsztatów jordanowskich. W latach 19081918 ukazało się 13 dodatków.

${ }^{36}$ H. Jordan powołał specjalną organizację młodzieżową „Pułk dzieci Krakowskich”, rozwiązaną przez władze austriackie.

37 Henryk Jordan na zjeździe kierowników warsztatów jordanowskich tak o tym powiedział: „...W czasach obecnych może to niezły sposób demokratyzowania społeczeństwa”, „Muzeum” 1911, t. III, dodatek 7 .

Jordan i jego prace prezentowane były wielokrotnie w czasopiśmie „Muzeum” 1890, 1893, 1900, 1907, 1910, 1912.

38 J. Jarowiecki, Czasopisma pedagogiczne we Lwowie w okresie autonomii galicyjskiej, [w:] Społeczeństwo, kultura, inteligencja, red. E. Orman, G. Nieć, Kraków 2009. 
W działalności wydawniczej Towarzystwa Nauczycieli Szkół Wyższych, poza czasopismem „Muzeum”, z największą troską odnoszono się do wydawania podręczników szkolnych i to już od II walnego zgromadzenia TNSW, czyli od 1885 r. Towarzystwo zwróciło się do sejmu krajowego o przywrócenie dotacji na nagrody za najlepsze podręczniki dla młodzieży szkół średnich w kwocie 2000 koron. Sejm krajowy ku niezmiernej satysfakcji TNSW przywrócił dotację, zainicjowano dyskusję w kołach TNSW nad planem prac dotyczących podręczników, konkursów, recenzji oraz druku. Towarzystwo z myślą o potrzebach młodzieży szkolnej przystąpiło też do wydawania serii książek autorów klasycznych greckich i łacińskich. Rozważne i umiejętne traktowanie spraw wydawniczych pozwoliło na znakomity rozwój akcji wydawniczej podręczników, wśród których odnotowano, licząc od 1885 r., kilkadziesiąt pozycji z algebry i arytmetyki, chemii, zoologii, logiki, religii, kaligrafii, filologii klasycznej, geografii. Nowy dział wydawniczy wyodrębniono w listopadzie 1890 roku, uruchamiając serię wydawniczą arcydzieł literatury polskiej i obcej w języku polskim dla młodzieży szkół średnich, przewidzianych do lektury domowej. Dobór lektur wiązano z ich treścią, formą, czystością i poprawnością języka oraz stylu. Wydawnictwo miało służyć doskonaleniu znajomości języka polskiego u młodzieży. Właśnie w ramach tej serii zatytułowanej „Biblioteka dla Młodzieży” ukazało się w latach 1891-1896 szesnaście tomików. Niestety, wydawnictwo nie doczekało się wsparcia sejmu krajowego, choć Rada Szkolna Krajowa wyraziła swoją aprobatę. Zawieszono wydawanie książek aż do roku 1900, kiedy na zjeździe TNSW uchwalono wznowienie wydawnictwa pod tytułem „Biblioteka Towarzystwa Nauczycieli Szkół Wyższych”. Oprócz nowych dzieł zamierzano opublikować przedruki wybitnych utworów literatury narodowej z przedmową i objaśnieniami wydawcy. Z kolei z serii „Biblioteka TNSW” zrodziło się nowe Wydawnictwo zatytułowane „Nauka i Sztuka”. Plan przedstawiony przez Tadeusza Piniego uzyskał aprobatę towarzystwa. Od 11 listopada 1905 r. Seria „Nauka i Sztuka” miała obejmować monografie o charakterze popularnonaukowym z różnych dziedzin: historii politycznej, historii sztuki, historii literatury, nauk przyrodniczych, a na planie pierwszym stawiała kulturę polską oraz cywilizację europejską. W kołach terenowych Towarzystwa również podejmowano działalność wydawniczą, a Krakowskie Koło TNSW uruchomiło pod koniec roku 1887 wydawnictwo „Biblioteka Pedagogiczna”, którego pierwszy tom ukazał się w Krakowie w $1888 \mathrm{r}$.

Czasopismo „Muzeum”, pod względem objętości, ale też bogactwa i poziomu merytorycznego artykułów i rozpraw, mogło śmiało konkurować z najlepszymi pismami tego typu w Europie i Stanach Zjednoczonych Ameryki Północnej. Od 1885 do 1912 roku opublikowano 27 tomów bardzo obszernych, choć z uwagi na różne formaty poszczególnych zeszytów dość trudnych do „podliczenia”, które do dziś stanowią niezastąpione źródło wiedzy pedagogicznej ${ }^{39}$. Wyrazem troski o poziom gimnazjów było m.in. opublikowanie na łamach „Muzeum” w 1914 r.

39 Por. Verus, O przepełnieniu naszych gimnazjów, „Muzeum” 1906; [b.a.], Nowe rządy, „Muzeum” 1905; A. Karbowiak, Obecne systemy wychowawcze na ziemiach polskich w 3 zaborach, „Muzeum" 1905. 
Memorjału Senatu Akademickiego Wszechnicy Jagiellońskiej do Rady Szkolnej Krajowej w sprawie złego przygotowania młodzieży szkół średnich w Galicji do studiów wyższych ${ }^{40}$. Czasopismo przez wiele lat walczyło też o poprawę bytu materialnego nauczycieli szkół średnich, a także opracowanie pragmatyki nauczycielskiej, wiele uwagi poświęcając kwestii suplenckiej. W okresie międzywojennym „Muzeum” odgrywało rolę jednego z najbardziej opiniotwórczych periodyków, na jego łamach przedstawiono projekty reformy szkolnictwa ministrów Wyznań Religijnych i Oświecenia Publicznego: Tadeusza Łopuszańskiego, Stanisława Grabskiego, Gustawa Dobruckiego, Janusza Jędrzejewicza oraz nauczycieli szkół średnich Romana Zawilińskiego czy Gustawa Felińskiego. W dyskusji nad ustawami jędrzejewiczowskimi TNSW znalazło się w szeregach opozycji, dając wyraz zaniepokojeniu o poziom szkół powszechnych oraz o gwarancje dla szkół prywatnych w zakresie swobody organizacyjno-programowej. W okresie reformy jędrzejewiczowskiej szerzej zajęto się kwestią wychowania narodowego i państwowego, a także określeniem ideału i celów wychowania ${ }^{41}$. Na uwagę zasługuje artykuł napisany przez Maksymiliana Tazbira na temat szkół prywatnych ${ }^{42}$. Nowy etap w dziejach gimnazjów prywatnych zaczynał się po 1905 r. Jak zauważył autor, bardzo niepokojącym zjawiskiem był spadek liczby uczniów szkół średnich, a mimo to w pracy tych szkół pojawił się jeden niezaprzeczalny walor „najistotniejsze posłannictwo: mogą stawać się doświadczalnymi ogniskami nowych kierunków wychowawczych”. Jak pisał M. Tazbir, „gimnazja prywatne mnożą się z roku na rok i cieszą dużą pieczołowitością zarówno społeczeństwa, jak i nauczycielstwa, starającego się wprowadzić nowoczesne metody nauczania i budzić dokoła nich ożywiony ruch pedagogiczny, głównie na gruncie Stowarzyszenia Nauczycielstwa Polskiego"43.

Pozytywna ocena szkół średnich prywatnych wynikała m.in. z ich udziału w walce o narodowy charakter szkoły (polskiego „ducha szkoły”), a także roli „zaczynu polskiego systemu szkolnego”. W latach 1924-1926 szkolnictwo prywatne rozwijało się bardzo intensywnie; w roku szkolnym 1926/1927, jak podał M. Tazbir, istniało 457 szkół, pracowało w nich 8412 nauczycieli (wg „zajętych posad”, bo wielu nauczycieli pracowało w dwu lub więcej szkołach"), uczyło się w nich 97 tys. uczniów ${ }^{44}$. Niestety, na początku lat trzydziestych, choć wzrosła liczba dzieci w wieku szkolnym, zmniejszyła się liczba uczniów w szkołach prywatnych

40 Rezultatem było m.in. Utworzenie Krakowskiej Komisji Planów i Podręczników, która po I wojnie światowej pracowała nad organizacją szkoły polskiej. Por.: B. Łuczyńska, Towarzystwo Nauczycieli Szkół Wyższych wobec problemów nauczycieli szkół średnich (1884-1918), „Rocznik Komisji Nauk Pedagogicznych PAN" 1984, t. XXXII.

41 L. Jaxa-Bykowski, Zagadnienia naszej polityki szkolnej, „Muzeum” 1926; B. Nawroczyński, Tempo rozwoju społecznego a zadania wychowawcze naszego pokolenia, „Muzeum” 1927; S. Łempicki, O ideał wychowania w Polsce, „Muzeum” 1929; Z. Mysłakowski, Wychowanie państwowe a narodowe, „Muzeum” 1931; S. Sośnicki, Zagadnienie wykształcenia ogólnego, „Muzeum”1930; M. Tazbir, Prywatne szkolnictwo średnie w Polsce, „Muzeum” 1934; K. Sośnicki, Naczelne idee pedagogiczne w Ustawie ustrojowej i programie szkoły średniej ogólnokształcącej, „Muzeum” 1939 i inne.

42 M. Tazbir, Prywatne szkolnictwo średnie w Polsce, „Muzeum” 1934, z. 4, s. 161-167.

43 „Muzeum” 1934, z. 4, s. 162.

44 Tamże. 
(maleją możliwości finansowe społeczeństwa - okres ogólnej pauperyzacji). Najwięcej uczniów rezygnowało z nauki w gimnazjach matematyczno-przyrodni$\mathrm{Czych}^{45}$. Dostęp do wszystkich uczelni mieli absolwenci gimnazjów humanistycznych, natomiast ci, którzy kończyli szkoły średnie matematyczno-przyrodnicze, dopóki nie złożyli egzaminu uzupełniającego z łaciny, mieli zamkniętą drogę na wydziały prawny, humanistyczny, lekarski, farmaceutyczny, weterynaryjny. Spadek liczby uczniów był „zatrważający, dotyczy bowiem głównie sfer rolniczych i rzemieślniczych"46. Na korzyść szkolnictwa prywatnego przemawiał fakt, że mogły stawać się doświadczalnymi ogniskami nowych kierunków wychowawczych ${ }^{47}$. Ustawa z 11.03.1932 r. nadzór i "opiekę" nad szkołami prywatnymi powierzyła Ministerstwu Wyznań Religijnych i Oświecenia Publicznego, a w art. 9 szkołom prywatnym uznanym przez Ministerstwo za eksperymentalne zapewniała „szczególną opiekę władz szkolnych".

Nowe prądy pedagogiczne wpływały na poziom pracy szkół średnich. Kazimierz Sośnicki w artykule Naczelne idee pedagogiczne dokonał analizy programu nauczania w szkołach średnich ogólnokształcących. Najwięcej uwagi poświęcił części wstępnej programu zatytułowanej Podstawy ideowe szkoły ogólnokształcącej, która składa się z dwóch komponentów: 1. ogólnych celów wychowania i wykształcenia, 2. celów szczegółowych. Za naczelny cel wychowania w programie szkolnym uznano „wychowanie i kształcenie na świadomych swych obowiązków i twórczych obywateli Rzeczpospolitej”. Cele drugie w kolejności, czyli cele szczegółowe, miały prowadzić do „rozwijania wszechstronnej osobowości przez urabianie w dziedzinie religijnej, moralnej, umysłowej i fizycznej" 48 . W kolejnych sformułowaniach, na które zwrócił uwagę Sośnicki, a mianowicie „budzenie swoistych sił u młodzieży”, „tworzenie u ucznia własnych nowych wartości”, „samoistne przetwarzanie dóbr ogólnoludzkich”, mieścił się wyraźnie pierwiastek indywidualny w wychowaniu, stwarzający dla spójnego systemu pedagogicznego trudność wynikającą z konieczności pogodzenia interesów jednostki z interesem państwa (wychowania państwowego). Ustawa ustrojowa z 1932 r. powstała w czasie, w którym „zdawało się, że w Polsce bierze górę raczej autorytet państwa nad indywidualnością obywatela”, natomiast „Program” popychał polski system pedagogiczny ku demokratyzmowi. Dalej K. Sośnicki przechodzi do analizy poszczególnych celów wychowania moralnego, umysłowego, społeczno-obywatelskiego, gospodarczego, fizycznego i państwowego. Niepokoił go brak wychowania religijnego. „Program, opuszczając wychowanie religijne, w miejsce niego wprowadza mistykę tajemniczych mocy, z których ma wyrastać moralność człowieka”, w związku z czym niejasne stało się określenie „nieprzemijające wartości etyczne”, a w konkluzji „tymczasowość” całego programu. Podsumowując swoje uwagi, Sośnicki napisał, że nowoczesność programu szkoły średniej sprowadza się do zamieszczania w nim różnych haseł, często sprzecznych (psychologizm a obiektywizm, indywidualizm a uspołecznienie, idealizm a realistyczny utylita-

45 Tamże, s. 163.

46 „Muzeum” 1934, z. 4, s. 164.

47 Tamże, s. 167.

48 K. Sośnicki, Naczelne idee pedagogiczne, „Muzeum” 1939, z. 1-2, s. 16-19. 
ryzm, liberalizm a totalizm), czego rezultatem jest popadanie w praktyce szkolnej w skrajności, osłabienie autorytetu szkoły i coraz bardziej powszechne narzekanie na nią. W okresie przedwojennym w „Muzeum” najwięcej miejsca przeznaczano na omawianie problemów dydaktycznych. W kręgu tematyki dydaktycznej mieściła się interesująca wypowiedź Romana Ingardena O roli podręcznika w nauczaniu w szkole średniej49. Autor zwrócił uwagę na dwa przeciwstawne stanowiska, które zajmowali nauczyciele: 1. podręcznik jest właściwie niepotrzebny (może tylko z wyjątkiem nauczania filologii klasycznej i języków nowożytnych), a o wartości wyników nauczania rozstrzyga nauczyciel; 2. nauczanie należy oprzeć głównie na podręczniku, a rolę nauczyciela ograniczyć do minimum. R. Ingarden starał się przedstawić i uzasadnić trzecie stanowisko, w którym uzupełniają się nawzajem tzw. żywe nauczanie nauczyciela we współpracy z uczniami oraz uczenie się uczniów przy użyciu podręcznika. Szeroko też omówił najważniejsze funkcje dobrego podręcznika szkolnego, do których zaliczał: podanie uczniom przerobionej na lekcjach części materiału nauczania w sposób rzeczowo, logicznie uporządkowany; uwzględnianie różnic między uczniami („może być stosowny w tempie odpowiadającym typowi umysłowemu czytelnika i w takich dawkach, jakie mu są wygodne, a także odmiennego stylu pracy intelektualnej"); wyrabianie umiejętności samodzielnego myślenia i pokonywania trudności; łączenie często odległych od siebie w czasie treści lekcji i „poprawiający pracę nauczycieli”; pomocny do pamięciowego utrwalania wiedzy (proces zapamiętywania wymaga wielokrotnego powtarzania), bez którego nie ma żadnej wiedzy „gotowej”, potrzebnej w dalszym kształceniu się i w życiu praktycznym ${ }^{50}$. Warto jeszcze odnotować wypowiedź Romana Dyboskiego zatytułowaną Postulaty neofilologiczne ${ }^{51}$. Była to relacja z trzeciego Zjazdu Neofilologów, który odbył się w Warszawie, a poświęcony był zagadnieniom szkolnej polityki językowej. Wśród 750 szkół średnich ogólnokształcących w Polsce w blisko 700 nauczano języka niemieckiego, w nieco ponad 500 - języka francuskiego, a tylko w 48 - języka angielskiego. R. Dyboski zwracał uwagę, że językiem dwóch największych mocarstw świata jest język angielski i że ten właśnie język staje się „narzędziem powszechnego porozumienia”. Domagał się, by MWRiOP, uwzględniając rezolucję uczestników zjazdu, wprowadziło do szkół średnich obowiązkową naukę drugiego języka obcego oraz zadbało o wysokie kwalifikacje nauczycieli neofilologów w szkołach średnich.

W materiałach publikowanych w wydawnictwach TNSW w latach 1921-1928 dadzą się wyodrębnić następujące zakresy tematyczne: filologia, pedagogika, polonistyka, nauki matematyczno-przyrodnicze, przygotowanie młodzieży do studiów wyższych, zagadnienia oceny i klasyfikacji szkolnej, ministerialny program gimnazjum państwowego. Od 1928 r. treść pisma „Muzeum” obejmowała cztery działy: artykuły dotyczące aktualnych zagadnień polityki szkolnej; rozprawy naukowe; wskazówki metodyczne i przykłady praktyki szkolnej; a także sprawozdania z ruchu pedagogicznego w kraju i za granicą. W latach trzydziestych wyeksponowano

49 R. Ingarden, Rola podręcznika w nauczaniu średnim, „Muzeum” 1939, z. 1-2, s. 69-96.

50 Dla wzmocnienia swojego stanowiska Ingarden powołuje się na pracę Z. Mysłakowskiego, Nauczanie żywe a podręcznik szkolny, wydaną we Lwowie w 1936 r.

51 R. Dyboski, Postulaty neofilologiczne, „Muzeum” 1939, z. 1-2, s. 96-105. 
następującą problematykę: przygotowanie do pracy i rola nauczyciela (artykuły R. Skulskiego, Z. Ziembińskiej, B. Gaweckiego, R. Dyboskiego); metodyka nauczania w szkole średniej (artykuły J. Kijasa, K. Frycza, W. Hahna, A. Hłasko-Pawlicowej, L. Jaxy-Bykowskiego, Z. Skorskiego, M. Kędziora); programy szkół średnich (wypowiedzi K. Frycza, T. Witwickiego, A. Skulskiej, E. Turkiewicza, K. Brończyka, S. Zetowskiego, J. Kijasa, A. Hodbod, W. Kowalenko); szkolnictwo w innych krajach (od 1933 r. cykl o szkolnictwie francuskim oraz materiały o szkołach w Niemczech, Anglii, USA autorstwa m.in. W. Olszewskiego, W. Gottlieba, G. Pola, A. Zieleńczyka, A. Ryniewicza, T. Strumiłło); podręczniki i książki szkolne (A. Kłodziński, Z. Czerny, S. Loges i in. $)^{52}$. Na uwagę zasługuje także szerokie spektrum informacji o codziennej pracy szkół średnich, o nowościach pedagogicznych, które pojawiały się w wyniku popularyzacji idei „nowego wychowania", ale również w wyniku narodzin polskiej pedagogiki, w tym nurtu badań nad nauczycielem (pedeutologii) oraz badań porównawczych (komparatystyki). Debiuty naukowe oraz liczne prace polskich uczonych (np. B. Nawroczyńskiego, K. Sośnickiego, J. Hulewicza), przegląd międzynarodowego ruchu naukowego, relacje z kongresów i zjazdów, biogramy (wspomnienia pośmiertne) polskich uczonych, nowości wydawnicze i szereg innych ciekawych materiałów, stanowią bogate źródło informacji nie tylko do badań nad dziejami czasopiśmiennictwa polskiego, ale także dziejami polskiej myśli pedagogicznej i przemianami szkolnictwa średniego ${ }^{53}$.

\section{Podsumowanie}

Dorobek Towarzystwa Nauczycieli Szkół Wyższych zasługuje na najwyższe uznanie pod wieloma względami:

- Wydawnictwa TNSW stworzyły możliwość publikowania wyników badań naukowych profesorom szkół średnich i wyższych.

- Umożliwiły przepływ informacji i upowszechniły znajomość podstaw prawa oświatowego.

- Wpływały na podnoszenie poziomu pracy nauczycieli oraz na ich doskonalenie zawodowe.

- Sprzyjały podejmowaniu oraz rozwojowi badań bibliograficznych i informacji naukowej.

- Przyniosły opublikowanie setek podręczników szkolnych oraz książek beletrystycznych dla młodzieży.

- Stanowiły wzór staranności i nowoczesności w zakresie edytorstwa wydawnictw szkolnych (bogato ilustrowane, zaopatrzone w fotografie, szkice, reprodukcje, ryciny, tabele, wzory).

52 Przykładowo E. Witkowska-Urban, Prywatne Gimnazjum Żeńskie Zofii Pętkowskiej i Wiktorii Macińskiej w Łodzi w latach 1918-1939, [w:] Tradycje i współczesność..., s. 31.

${ }^{53}$ Por. I. Michalska, Łódzka szkoła średnia w lokalnej prasie codziennej Drugiej Rzeczpospolitej, [w:] Tradycje i współczesność..., s. 50. 
- Motywowały nauczycieli i dyrektorów szkół do stosowania nowych rozwiązań metodycznych. Stwarzały pole do dyskusji na temat reform oświatowych.

- Popularyzowały „nową szkołę” w zakresie przemian organizacyjnych oraz dydaktycznych.

- Rozwijały zainteresowania czytelnicze młodzieży szkolnej. w Polsce.

- Były zaczynem nowoczesnego bibliotekarstwa i ruchu księgarskiego

- Zainicjowały liczne zmiany w funkcjonowaniu szkół średnich w Polsce współczesnej.

- Bogactwo materiałów opublikowanych w czasopismach i drukach zwartych TNSW stanowi podstawę opracowywania kolejnych rozpraw naukowych oraz prac zbiorowych ${ }^{54}$.

Tradycje Wydawnicze TNSW kontynuuje po II wojnie światowej Polskie Przedsiębiorstwo Wydawnictw Kartograficznych im. Eugeniusz Romera w Warszawie.

54 Por:: G. Wrona, Lwowskie czasopisma naukowe w latach 1918-1939, [w:] Kraków - Lwów. Książki - czasopisma - biblioteki XIX i XX wieku, red. J. Jarowiecki, „Prace Monograficzne WSP w Krakowie" 1999, t. IV, nr 258; Bibliografia dziejów oświaty i wychowania..., cz. II: Źródła drukowane, Rzeszów 2007. 